\title{
Developing European conservation and mitigation tools for pollination services: approaches of the STEP (Status and Trends of European Pollinators) project
}

Article

Published Version

Potts, S., Biesmeijer, J. C., Bommarco, R., Felicioli, A., Fischer, M., Jokinen, P., Kleijn, D., Klein, A.-M., Kunin, W. E., Neumann, P., Penev, L. D., Petanidou, T., Rasmont, P., Roberts, S., Smith, H. G., Sørensen, P. B., Steffan-Dewenter, I., Vaissière, B. E., Vilà, M., Vujić, A., Woyciechowski, M., Zobel, M., Settele, J. and Schweiger, O. (2011) Developing European conservation and mitigation tools for pollination services: approaches of the STEP (Status and Trends of European Pollinators) project. Journal of Apicultural Research, 50 (2). pp. 152-164. ISSN 0078-6913 doi: https://doi.org/10.3896/IBRA.1.50.2.07 Available at https://centaur.reading.ac.uk/24711/

It is advisable to refer to the publisher's version if you intend to cite from the work. See Guidance on citing.

To link to this article DOI: http://dx.doi.org/10.3896/IBRA.1.50.2.07

Publisher: IBRA 
All outputs in CentAUR are protected by Intellectual Property Rights law, including copyright law. Copyright and IPR is retained by the creators or other copyright holders. Terms and conditions for use of this material are defined in the End User Agreement.

\section{www.reading.ac.uk/centaur}

\section{CentAUR}

Central Archive at the University of Reading

Reading's research outputs online 


\title{
Developing European conservation and mitigation
}

\section{tools for pollination services: approaches of the STEP (Status and Trends of European Pollinators) project}

\begin{abstract}
Simon G Potts ${ }^{1 *}$, Jacobus C Biesmeijer ${ }^{2,3}$, Riccardo Bommarco ${ }^{4}$, Antonio Felicioli ${ }^{5}$, Markus Fischer ${ }^{6}$, Pekka Jokinen ${ }^{7}$, David Kleijn ${ }^{8}$, Alexandra-Maria Klein ${ }^{9}$, William E Kunin' ${ }^{2}$, Peter Neumann ${ }^{10}$, Lyubomir D Penev $^{11}$, Theodora Petanidou ${ }^{12}$, Pierre Rasmont ${ }^{13}$, Stuart P M Roberts ${ }^{1}$, Henrik G Smith ${ }^{14}$, Peter B Sørensen ${ }^{15}$, Ingolf Steffan-Dewenter ${ }^{16}$, Bernard E Vaissière ${ }^{17}$, Montserrat Vilà ${ }^{18}$, Ante Vujić ${ }^{\prime 9}$, Michal Woyciechowski ${ }^{20}$, Martin Zobel ${ }^{21}$, Josef Settele ${ }^{22}$ and Oliver Schweiger ${ }^{22}$
\end{abstract}

${ }^{1}$ School of Agriculture, Policy and Development, University of Reading, Reading, RG6 6AR, UK.

${ }^{2}$ Institute of Integrated and Comparative Biology, University of Leeds, Leeds, LS2 9JT, UK.

${ }^{3}$ Netherlands Centre for Biodiversity Naturalis, PO Box 9517, 2300 RA Leiden, Netherlands.

${ }^{4}$ Swedish University of Agricultural Sciences, Department of Ecology, SE-75007 Uppsala, Sweden.

${ }^{5}$ Department of Physiological Sciences, University of Pisa. Viale delle Piagge 2, 56124, Pisa, Italy.

${ }^{6}$ Institute of Plant Sciences, University of Bern, Altenbergrain 21, CH-3013, Bern, Switzerland.

${ }^{7}$ Finnish Environment Institute, Joensuu Office, PO Box 111, 80101 Joensuu, Finland.

${ }^{8}$ Alterra, PO Box 47, 6700 AA, Wageningen, Netherlands.

${ }^{9}$ Institute of Ecology, Ecosystem functions, Leuphana University of Lüneburg, Scharnhorststraße 1, 21335 Lüneburg, Germany.

${ }^{10}$ Swiss Bee Research Center, Agroscope Liebefeld-Posieux Research Station ALP, CH-3003 Bern, Switzerland.

${ }^{11}$ Pensoft Publishers Ltd, Geo Milev 13a, Sofia, 1111, Bulgaria.

${ }^{12}$ Laboratory of Biogeography and Ecology, Department of Geography, University of the Aegean, University Hill, GR-81100 Mytilene, Greece.

${ }^{13}$ Service de Zoologie, Université de Mons-Hainaut, Place du Parc, 20, B-7000 Mons, Belgium.

${ }^{14}$ Department of Biology \& Centre of Environmental and Climate Research, Lund University, S-223 62 Lund, Sweden.

${ }^{15}$ National Environmental Research Institute, Department of Terrestrial Ecology, Aarhus University, Denmark.

${ }^{16}$ Department of Animal Ecology and Tropical Biology, Biocenter, University of Würzburg, Am Hubland, 97074 Würzburg, Germany.

${ }^{17}$ Institut National de la Recherche Agronomique, UMR 406 Abeilles et Environnement, Pollination and Bee Ecology Unit, 84914 Avignon cedex 9, France.

${ }^{18}$ Estación Biológica de Doñana (EBD-CSIC), Isla de la Cartuja, Avda.Américo Vespucio, s/n, 41092 Sevilla, Spain.

${ }^{19}$ University of Novi Sad, Department of Biology and Ecology, Trg Dositeja Obradovica 2, 21000 Novi Sad, Serbia.

${ }^{20}$ Institute of Environmental Sciences, Jagiellonian University, Gronostajowa 7, 30-387 Krakow, Poland.

${ }^{21}$ Institute of Ecology and Earth Sciences, University of Tartu, Lai 40, Tartu, 51005, Estonia.

${ }^{22}$ UFZ, Helmholtz Centre for Environmental Research - UFZ, Department of Community Ecology, Theodor-Lieser-Str. 4, 06120 Halle, Germany.

Received 13 January 2011, accepted subject to revision 4 February 2011, accepted for publication 7 March 2011.

*Corresponding author: Email: s.g.potts@reading.ac.uk

\section{Summary}

Pollinating insects form a key component of European biodiversity, and provide a vital ecosystem service to crops and wild plants. There is growing evidence of declines in both wild and domesticated pollinators, and parallel declines in plants relying upon them. The STEP project (Status and Trends of European Pollinators, 2010-2015, www.step-project.net) is documenting critical elements in the nature and extent of these declines, examining key functional traits associated with pollination deficits, and developing a Red List for some European pollinator groups. Together these activities are laying the groundwork for future pollinator monitoring programmes. STEP is also assessing the relative importance of potential drivers of pollinator declines, including climate change, habitat loss and fragmentation, agrochemicals, pathogens, alien species, light pollution, and their interactions. We are measuring the ecological and economic impacts of declining pollinator services and floral resources, including effects on wild plant populations, crop production and human nutrition. STEP is reviewing existing and potential mitigation options, and providing novel tests of their effectiveness across Europe. Our work is building upon existing and newly developed datasets and models, complemented by spatially-replicated campaigns of field research to fill gaps in current knowledge. Findings are being integrated into a policy-relevant framework to create evidence-based decision support tools. STEP is establishing communication links to a 
wide range of stakeholders across Europe and beyond, including policy makers, beekeepers, farmers, academics and the general public. Taken together, the STEP research programme aims to improve our understanding of the nature, causes, consequences and potential mitigation of declines in pollination services at local, national, continental and global scales.

\section{Desarrollo de herramientas europeas de conservación y mitigación de los servicios de polinización: enfoques del proyecto STEP (Estado y tendencias de los polinizadores europeos)}

\section{Resumen}

Los insectos polinizadores forman un componente clave de la biodiversidad europea, y proporcionan servicios vitales a los ecosistemas de plantas cultivadas y silvestres. Existe una creciente evidencia del declive de polinizadores silvestres y domesticados, y del declive paralelo de las plantas que dependen de ellos. El proyecto STEP (Estado y tendencias de los polinizadores europeos, 2010-2015, www.step-project.net) está documentando elementos críticos en la naturaleza y la extensión de estos declives, examinando características funcionales claves asociadas con el déficit de polinización, y desarrollando una Lista Roja de grupos de polinizadores europeos. Todas estas actividades juntas suponen el trabajo preliminar base para futuros programas de monitorización de polinizadores. STEP también investiga la importancia relativa de factores potenciales del declive de polinizadores, incluido el cambio climático, pérdida de hábitats y fragmentación, agroquímicos, patógenos, especies invasoras, contaminación lumínica, y otras interacciones. Se están midiendo los impactos ecológicos y económicos del declive de los servicios de polinizadores y de sus fuentes florales, incluyendo los efectos en las poblaciones de plantas silvestres, producción de cultivos y la alimentación humana. STEP está revisando las opciones de mitigación potenciales y las existentes, y proporcionando nuevos tests para su eficacia a lo largo de Europa. El trabajo se basa en modelos y conjuntos de datos desarrollados de novo y en otros ya existentes, complementados con campañas de trabajo de campo con replicación espacial para crear herramientas de soporte de decisiones basadas en la evidencia. STEP está estableciendo nexos de comunicación con un rango amplio de participantes a lo largo de Europa y fuera de ella, incluyendo a políticos, apicultores, granjeros, académicos y el público general. En conjunto, el programa de investigación STEP quiere mejorar nuestra comprensión de la naturaleza, las causas, consecuencias y mitigación potencial del declive de servicios de polinización a escala global, continental, nacional y local.

Keywords: bees, crops, environmental pressures, flowering plants, pollinators, pollination services

\section{Introduction}

Halting biodiversity loss is a key international priority, and central to the Convention on Biological Diversity and EU policy. The majority of global (and European) biodiversity is made up of insects and other invertebrate taxa, but little is known of the distributions and abundance of most species, and even less is known about their population dynamics and the threats they face. This lack of knowledge concerning the status and trends of the majority of species is worrying, but there is even greater concern for species that play important functional roles, such as pollinators (NRC, 2006; Potts et al., 2010a). Pollination is an essential ecosystem service, vital to the maintenance both of wild plant communities and agricultural productivity; and pollinators themselves can act as indicators of environmental health (Kevan, 1999). The value of insect pollination to European agriculture is estimated to be worth $€ 22$ billion per year (Gallai et al., 2009) with $84 \%$ of European crop varieties dependent, at least in part, on insect pollinators (Williams, 1994). Wildflowers are also highly dependent on insects for their reproduction, with an estimated $78-94 \%$ of flowering species relying on biotic pollination (Ollerton et al., 2011).
Pollination services depend on both managed and unmanaged pollinator populations, and both may be affected by a range of recent and projected future environmental changes, with unknown consequences. Managed honey bees (Apis mellifera) have undergone severe declines in Europe since 1985, with a mean overall loss of $16 \%$, with greater losses in central Europe (25\%) and England (54\%) (Potts et al., 2010b). There are also more than 2,000 species of nonApis bees in Europe, and where evidence is available, such as the UK, Netherlands and Belgium, there have been serious declines in the diversity and abundance of these bees (Rasmont and Mersch, 1988; Biesmeijer et al., 2006; Goulson et al., 2008). In parallel to the decline in pollinators, there have been losses of wild plants dependent upon insect pollination (Biesmeijer et al., 2006; Carvell et al., 2006).

The STEP ( tatus and Irends of European Pollinators, www.stepproject.net) Project is addressing these major challenges for the full range of pollinator taxa and associated pollination services. The project started in February 2010, and will run until 2015 and is funded by the European Commission within the 7th Framework Programme. The project is coordinated by the University of Reading, UK and combines the expertise of 20 research institutions from 17 European countries, and also has partners in Brazil, China, India and Russia. 
STEP complements other important initiatives operating in Europe,

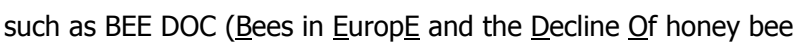
Colonies) and the global COLOSS (prevention of honey bee COlony LOSSes) network, both of which focus primarily on honey bees. In North America, two large-scale initiatives share many of the same aims of STEP, but address knowledge and policy needs for that region. These are CANPOLIN (CANadian POLlination Initiative) and NAPPC (№rth American Pollinator Protection Campaign). Other regional activities include the African Pollinator Initiative, Brazilian Pollinator Initiative and the Oceanic Pollinator Initiative.

\section{Overall aim and specific objectives}

The overall aim of STEP is to assess the current status and trends of pollinators in Europe, quantify the relative importance of various drivers and impacts of change, identify relevant mitigation strategies and policy instruments, and disseminate this to a wide range of stakeholders. This general aim is underpinned by seven specific objectives. To achieve these aims, STEP is structured into seven themes (Fig. 1) which reflect the main objectives of the project: Theme 1. Documenting the status and trends of pollinator (managed honey bees, non-Apis bees and hover flies) and animal-pollinated plant populations; Theme 2 . Identifying and analysing how single and multiple pressures drive changes in pollinators and animal-pollinated plants at scales ranging from single fields to landscapes to the whole of Europe; Theme 3. Assessing the impact of changes in pollinator populations and communities on wild plant reproduction and crop productivity; Theme 4. Synthesizing and evaluating strategies to mitigate the negative impacts of changes in pollinators and animalpollinated plants; Theme 5 . Empirically assessing effects of multiple pressures on pollinators and pollination services to wild plants and crops, and testing the effectiveness of potential mitigation actions; Theme 6. Analysing and improving the interface between the scientific knowledge-base on pollinator and pollination change assessment and

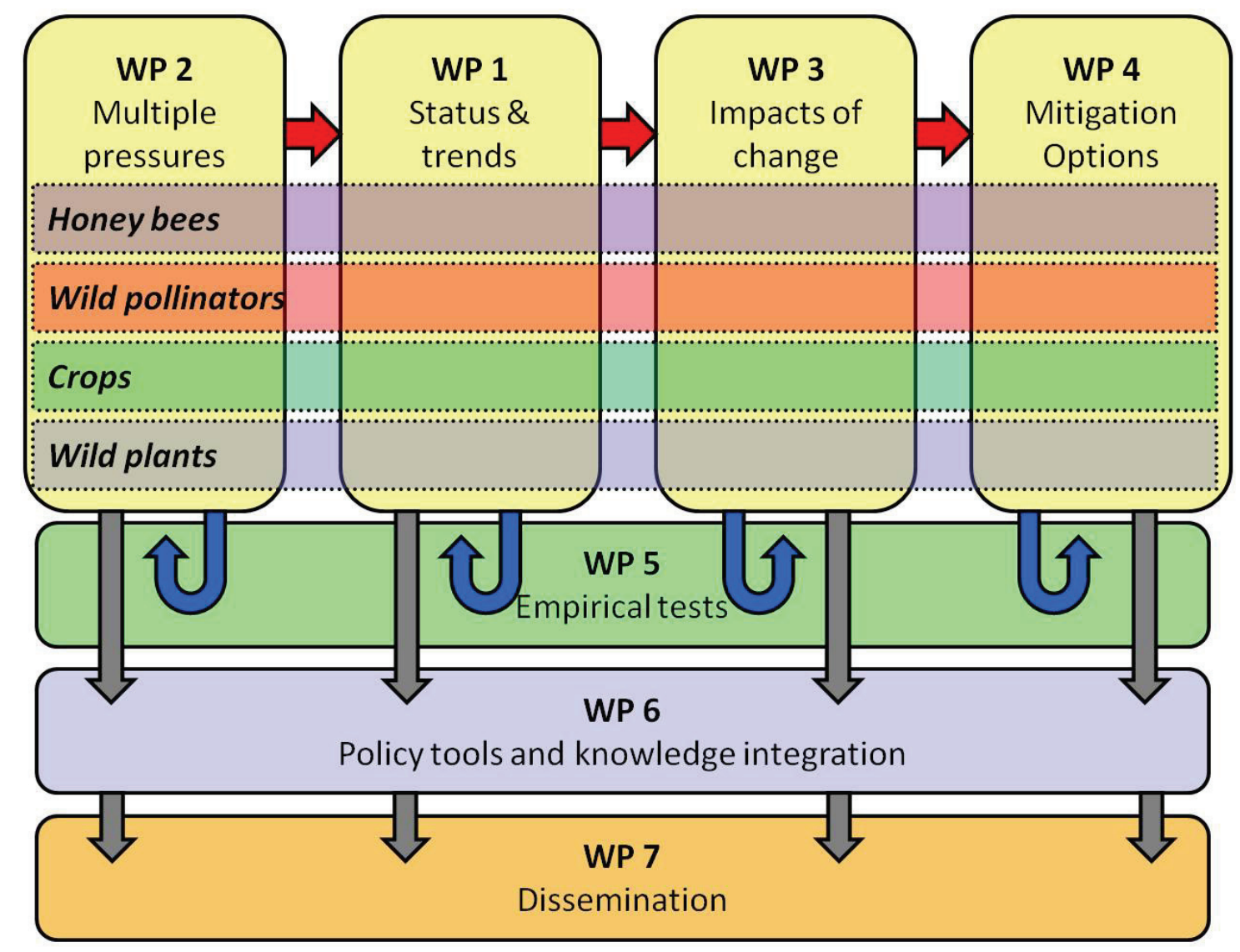

Fig. 1 The interrelations of the different themes (1 to 7) within the STEP project and the two main functional pollinator groups (honey bees and non-Apis pollinators) and plant groups (crops and wild plants) being studied. Red arrows indicate the flow of work from 'pressures' (Theme 2) which determine the 'status' of pollinators (Theme 1) which result in 'impacts' on the environment (Theme 3), for which negative consequences can be 'mitigated' (Theme 4). Blue arrows indicate the testing of hypotheses generated by Themes 1-4, which are 'empirically tested' in the network of field sites across Europe (Theme 5). Grey arrows indicate the flow of knowledge and evidence from the research Themes (1-5), which is 'integrated' (Theme 6) and then 'disseminated' (Theme 7). 
European policy instruments to reduce pollinator and pollination loss and mitigate its effects; and Theme 7. Developing communication and educational links with a wide range of stakeholders and the general public on the importance of recent shifts in pollinators, the main drivers and impacts of pollinator shifts and mitigation strategies through dissemination and training.

\section{Research approach and expected outcomes}

For each theme within STEP described below, we have identified the current state of knowledge and related research needs and then outline the approaches the project will take to move beyond the current state of the art.

\section{Theme 1: Status and trends of pollinators and animal-pollinated plant populations}

The first task of STEP is to assess the extent of recent changes in pollinator populations (particularly honey bees, non-Apis bees and hover flies) and in animal-pollinated wild plants and crops. Previous findings point to declines in some of these groups in parts of Europe at large scales (UK and Netherlands: Biesmeijer et al., 2006; Belgium: Rasmont et al., 1993; 2005; Potts et al., 2010b), but declines in other parts of Europe and changes at finer spatial scales are unknown. The biggest impediments to progress are that the relevant data are widely scattered and have been collected in non-standardized ways. To assess local scale change we are implementing rarefaction analyses at multiple spatial scales on collated point records for pollinators and on detailed botanical inventories. To assess change at continental scale, we are mapping species distributions using historic and current data from databases and collections.

The existing datasets of European plants and pollinators include many hundreds (indeed, for plants, many thousands) of different species. This means that results of individual species' responses will not necessarily contribute much to a general understanding of changes in plant-pollinator interactions. A functional level analysis would be an improvement, but needs detailed information on species traits. The STEP consortium combines the expertise needed to construct such trait databases for pollinators and animal-pollinated plants; work that will be based on existing data for hover flies (Speight, 2010; Syrph the Net; Vujic, unpublished data), bees (Roberts, unpublished data) and plants (e.g. Bioflor: Klotz et al., 2002; Kleyer et al., 2008). Another way to assess the status of species is to use expert knowledge. This has been used extensively, together with published information, to construct national Red Lists. Red Lists are a comprehensive inventory of the conservation status of plant and animal species and assess the risk of extinction to species within a political management unit. Several European countries have a
Red List for plants (e.g. Lilleleht, 1998) or bees (e.g. Gärdenfors, 2010), and there is a European Red List for butterflies (van Swaay et al., 2010). One goal of STEP is to apply standard IUCN criteria (Mace and Lande, 1991; Mace et al., 2008) to lay out the pathway towards the first European Red List for bees and hover flies.

The project will also assess the feasibility and bottlenecks for a large-scale monitoring programme for pollinators. Monitoring schemes have been extremely useful in providing standardized data for birds (Gregory and van Strien, 2010), butterflies (Freeman, 2009) and several other taxa (e.g. bats, http://www.bats.org.uk/pages/nbmp.html). A European pollinator monitoring scheme would have to overcome several serious issues. Firstly, there are fewer enthusiasts for pollinators than there are for butterflies or birds. Secondly, there are many species of bees and hover flies, which are often difficult to identify in the field. Thirdly, even when using recently developed sampling protocols (Westphal et al., 2008), the processing of the samples is not trivial. STEP is carrying out a feasibility analysis of pollinator monitoring schemes which will include sampling schemes as well as automated identification methods.

\section{Theme 2: Multiple pressures on pollinators and animal-pollinated plants}

Global change generates many drivers that affect pollinators (NRC, 2006; Winfree et al., 2009; Potts et al., 2010b) and animal-pollinated plants (Lavergne et al., 2006). Sustaining pollination services, for instance, is critical for both conservationists and farmers, but it is often negatively affected by anthropogenic practices such as increasing agricultural intensification (Potts et al., 2010a). Among the most important drivers of pollinator loss are land-use change with the consequent loss and fragmentation of habitats (Steffan-Dewenter et al., 2002; Westphal et al., 2003; Tscharntke et al., 2005; Schweiger et al., 2007), increasing pesticide application and environmental pollution (Rortais et al., 2005; Dormann et al., 2007), decreased resource diversity (Biesmeijer et al., 2006), alien species (Stout and Morales, 2009; Vilá et al., 2010), the spread of pathogens (Cox-Foster et al., 2007; Otterstatter and Thomson, 2008; Neumann and Carreck, 2010) and climate change (Hegland et al., 2009; Schweiger et al., 2011). Habitat loss and fragmentation are generally thought to be the most important factors driving pollinator declines (Brown and Paxton, 2009). In addition, increased use of insecticides can cause pollinator mortality by direct intoxication (Alston et al., 2007) and alter pollinator community structure (Brittain et al., 2010). Increased herbicides and fertilisers can affect pollinators indirectly by decreasing floral resource availability (Gabriel and Tscharntke, 2007; Holzschuh et al., 2008).

An additional threat is the introduction of alien plants and pollinators, but their effects can be highly variable and context specific (Schweiger et al., 2010). Aliens can serve as additional pollen and nectar sources (Stout and Morales, 2009) or pollinators (Goulson, 
2003), or they can lead to reduced reproductive success and population declines of native pollinators by competitive displacement of native plants (Traveset and Richardson, 2006) or by high levels of resource competition among native and alien pollinators (Matsumura et al., 2004; Thomson, 2006). There is also good evidence that translocated alien bees can increase the spread of pathogens and their vectors (Stout and Morales, 2009), but still little is known about inter- and intra-specific transfer and interactions with other drivers. Finally, climate change was shown to have already affected the distributions of many pollinators such as butterflies (Hickling et al., 2006) and future changes are likely to have even more severe impacts (Settele et al., 2008).

All these drivers act simultaneously, and probably synergistically, on pollinator communities (Tylianakis et al., 2008). So far, most studies have analysed specific drivers in isolation, and therefore evidence of interactive effects is scant (but see Schweiger et al., 2010). Knowledge about the relative contribution and the importance of interactive effects is, however, an indispensable precondition to understanding current and to predicting future changes in pollinators, animal-pollinated plants and resulting pollination services.

STEP addresses all of the above-mentioned drivers individually and investigates their interactions, using a combination of approaches at complementary spatial scales. A large-scale, macro-ecological approach is based on continental and national data on spatial and temporal distribution of managed and wild pollinators, animalpollinated plants and potential drivers to detect general relationships. A landscape-scale approach takes advantage of the higher resolution these studies provide, and case studies are used to address more specific questions. A small-scale, experimental approach allows a mechanistic understanding of the combined effects of selected drivers on managed and wild bees at the population and individual level. Across all scales, the combined effects of the relevant drivers are being assessed on different organisational levels, i.e. genes, populations, species, communities, interaction networks, species traits, functional groups, of wild and managed pollinators.

A major contribution of STEP is that modelling exercises at the large scale will expand our knowledge of independent and synergistic effects of the multiple drivers on the phenology, distribution and performance of pollinators and animal-pollinated plants. Ecological niche models are being developed for major European pollinator groups (bees, hover flies, and butterflies) and their host plants, to assess indirect effects of interacting species and to build current and future risk maps. Further, we are using expert workshops to analyse and synthesise current knowledge about relevant drivers on European pollinators and animal-pollinated plants at the landscape scale. Here, a special focus on the effects of alien species and the sensitivity to multiple drivers for species with shared life history traits is informing us about potential consequences of global change for local species richness and community composition, an approach successfully used by Williams et al. (2010). STEP is also shedding light on the impact of land-use and pesticides on the viability of honey bee colonies at the landscape scale. At the smallest scale, laboratory and field experiments are improving our understanding of the interaction of combined effects of parasites, pathogens and environmental pollutants on the performance of selected managed and unmanaged pollinators, the importance of chronic sub-lethal effects in combination with additional drivers, the transferability of usual risk assessment procedures during the approval of pesticides to field conditions, and the importance of intra-and inter-specific pathogen and parasite transfer from managed to unmanaged pollinators. The combined results from all scales and methodological approaches will improve our knowledge on the causes of recent major declines of European pollinators and help develop well-informed adaptation and mitigation strategies.

\section{Theme 3: Impacts of pollinator change on wild plants and crops}

The observation that both honey bees (De la Rúa et al., 2009) and other pollinators, and many plants they pollinate (e.g. Biesmeijer et al., 2006) appear to be declining in Europe and elsewhere (NRC, 2006), has raised concerns that insect pollination of wild and crop plants has become an endangered ecosystem function, but this remains largely unconfirmed as a widespread phenomenon. Indeed, the impact of pollinator declines on wild plants is grossly understudied (Tylianakis et al., 2008), although more than three quarters of all wild plant species depend on insect pollination for fruit and seed set (Ollerton et al., 2011). Of the plants that have been studied, $62-73 \%$ show pollination limitation (Burd, 1994; Ashman et al., 2004). Few studies have, however, proceeded to assess the consequences on plant survival, demography, and community composition (Lennartsson, 2002; Hegland and Totland, 2008).

Parallel declines of pollinators and pollinated plants suggest that there is a causal link between the two phenomena (Biesmeijer et al., 2006), but the nature of that link is not yet clear. It may be that declines in floral resources are contributing to pollinator declines. Alternatively, increasingly limited pollination may be contributing to wild plant declines, or indeed both. Further, the two phenomena may both be driven by the same or different external drivers. For instance, recent studies demonstrate that habitat loss and fragmentation can lead to drastic shifts in density (Hambäck et al., 2007, 2010) and species distribution patterns of communities of flower visiting insects (Bommarco et al., 2010; Öckinger et al., 2010), but the consequences of these shifts for pollination efficiency are not well understood. Indications that pollination might be important, is given in a meta-analysis covering 89 wild plant species in remnant habitat patches, where the most frequent cause of reproductive impairment was pollination limitation (Aguilar et al., 2006). 
Insect pollination is necessary for $75 \%$ of the crops that are used directly as human food worldwide (Klein et al., 2007), and cultivation of pollinator-dependent crops has steadily increased between 19612006 (Aizen et al., 2008). Despite this there is a severe lack of basic information on how species diversity, abundance and community composition of pollinating insects contribute to seed and fruit yield and quality in crops (Klein et al., 2007). Large economic values are at stake, with an estimated $\sim 10 \%$ of the total economic value of European agricultural output for human food amounting to $€ 22$ billion in 2005 ( $€ 14.2$ billion for the European Union), dependent upon insect pollination (Gallai et al., 2009). A complete pollinator loss would translate into a production deficit over current consumption levels of $-40 \%$ for fruits and $-16 \%$ for vegetables (Gallai et al., 2009). These estimates are, however, debatable and rest on uncertain estimates of the dependency of crops on insect pollination (especially for perennial crops such as fruit trees). Many of the pollinated crops are rich in micronutrients, such as vitamins and minerals. Current studies have estimated the value of pollinators only in terms of biomass produced and the particular value of the micronutrients contributing to the human diet has not been considered. The current decline of wild and domesticated insect pollinators emphasises the need to improve assessment of the potential consequences for crop productivity and economic output.

A key goal of STEP is to increase understanding of whether and how pollinator and plant losses are linked, and assess both how changes in floral resources may affect the pollinator fauna and how the community composition of pollinators might affect the diversity, community composition, seed set, and ultimately persistence and extinction risk of wild plants. Scattered information for this is available in the literature and databases. STEP is undertaking a synthesising analysis based on available data and statistics and complements these with empirical studies. To better estimate the impacts on crop pollination, STEP is developing a methodology and is quantifying the dependence on insect pollinators of major annual crops, perennial fruit tree and vine crops in Europe. STEP is also assessing the role of community composition and variation in domesticated and wild pollinators on the crop and nutrient production at the European and global scale. With this information, STEP is determining the impact of pollinator declines on insect-pollinated crop productivity and economy at a farm to global scale for key crops, including those important for food security and biofuels.

\section{Theme 4: Strategies to mitigate the impacts of change}

The ongoing decline of pollinators and pollination services can be mitigated by interventions on agricultural fields or in semi-natural habitats in the wider countryside (Dicks et al., 2010). Recent studies have shown that mitigation strategies on farmland generally benefit pollinators, but that their effect depends both on the type of measures and where they are being implemented (Kleijn et al., 2006; Kohler et al., 2007), what genus or order of pollinators is being targeted (Kohler et al., 2007) and the composition of the landscape (Heard et al., 2007; Holzschuh et al., 2007; Rundlöf et al., 2008). In agriculturally marginal areas, mitigation strategies are less successful in enhancing species richness of pollinators, but they do maintain the pollinator communities inhabiting these areas which are generally much more diverse than those inhabiting more intensively managed agricultural landscapes (Batáry et al., 2010). Few studies specifically examine effects of measures counteracting pollination loss caused by the ongoing decline of honey bees and other pollinators. The few available studies suggest that augmentation of pollination services by measures on farmland occurred only at local scales (e.g. Albrecht et al., 2007). Semi-natural habitats, such as nature reserves or edge habitats, are rarely managed for pollinators. In intensively managed landscapes they may nevertheless play an important role in the maintenance of a diverse pollinator community as they provide pollinators with nesting or forage sites that are generally lacking outside these areas. Protected areas may therefore serve as a source of pollinator species (Öckinger and Smith, 2007; Kohler et al., 2008) and pollination services (Ricketts et al., 2008). The decline of pollination services as a result of the ongoing decline of the honey bee may also be mitigated by managing pollinators other than honey bees. Currently a number of bee species are managed for pollination for a range of different crops. Examples are Megachile rotundata (alfalfa and some vegetable seed crops, North America; Bosch and Kemp, 2005); Bombus spp. (glasshouse crops, Europe, orchard crops, North America; Velthuis and van Doorn, 2006); Osmia spp. (almond, apple and other orchard crops, North America, Europe, Japan; e.g. Maccagnani et al., 2007).

STEP is reviewing the uptake of a wide range of conservation initiatives that can be expected to have beneficial effects on pollinators and pollination, such as nature reserves, agri-environment schemes or organic farming. Data are being collected from relevant institutions at European, national or regional scales. The project is synthesizing the results of all European studies examining the effects of conservation initiatives on wild and managed pollinators and measures mitigating pollination loss in crops. Results are being analyzed using a meta-analysis approach (e.g. Bengtsson et al., 2005; Winfree et al., 2009) to examine factors that contribute to success or failure. STEP aims to identify the mechanisms behind the successes and failures of different mitigation measures to conserve or enhance pollinators or pollination, by analyzing which life history traits pollinator species and crops are correlated with demonstrated positive effects of mitigation management, following approaches such as those used by Kleijn and Raemakers (2008) and using expert workshops. Finally, STEP is comparing the European uptake and distribution of mitigation measures with the demonstrated and expected 
effectiveness of mitigation measures. This comparison is providing the basis for the design of novel effective mitigation measures for areas that are poorly covered or improved mitigation measures for areas in which mitigation measures are currently being implemented. The most promising mitigation strategy will subsequently be field tested in large-scale field experiments as described under Theme 5.

The expected results include a European overview at the national scale of the uptake of conservation initiatives that may benefit pollinators and / or pollination services. STEP will furthermore produce an assessment of the effectiveness of existing strategies for mitigating pollinator loss. If sufficient data is available, this assessment will distinguish between different strategies and pollinator groups. STEP is also producing a review on which pollinator life history traits are key for successful mitigation and which crop traits facilitate successful mitigation against pollination loss. Finally, STEP will produce a short-list of promising novel or improved mitigation strategies counteracting pollinator and pollination loss.

\section{Theme 5: Empirical assessment of multiple pressures on pollinators and pollination services across Europe}

Global environmental change acts at multiple spatial scales from local habitats up to biogeographical regions (Kremen et al., 2007; Schweiger et al., 2011) and affects species richness, abundance and community composition of pollinators (Steffan-Dewenter, 2003; Meyer et al., 2009; Brückmann et al., 2010). Species characterised by particular life history traits, such as food specialists, small solitary bees and species at higher trophic levels, are expected to be more sensitive to changing environments (e.g. habitat loss and fragmentation; Steffan-Dewenter and Tscharntke, 2000; Bommarco et al., 2010; Öckinger et al., 2010). In addition, the way species respond at multiple spatial scales depends upon body size, foraging range and other species traits (Steffan-Dewenter et al., 2002; Schweiger et al., 2005; Westphal et al., 2006). Our knowledge is, however, still limited regarding the consequences of multiple pressures on functional community composition, population dynamics and landscape genetics of pollinators (Herrmann et al., 2007; Steffan-Dewenter and Schiele, 2008) and how significant combinations of pressures impact on pollinator assemblages (Bartomeus et al., 2010; Potts et al., 2010a; Schweiger et al., 2011).

In the light of actual and potential conflicts (c.f. synergies) between conservation and agriculture, the question of spill-over of pollinators and services between natural and agricultural ecosystems (Rand et al., 2006) is poorly understood at present. Also, the functional consequences of pollinator loss on plant-pollinator interaction networks and pollination services for wild plants and crops at landscape scales and in different climatic regions require further empirical assessments (Memmott et al., 2007; Höhn et al., 2008;
Dauber et al., 2010). In order to quantify long-term dynamics and future extinctions of pollinators, standardised, large-scale and longterm monitoring schemes are necessary but their design and scope need to be determined (Westphal et al., 2008; Kuussaari et al., 2009).

Theme 5 of STEP will provide the link between local experiments and case studies and continental-scale, data-based synthesis work and modelling performed in Themes 1 to 4 . Based on the synthesis and gaps identified in these themes, specific hypotheses are being formulated to address outstanding questions in our knowledge. Establishing a common network of study sites across Europe allows STEP to assess the combined effects of multiple pressures on pollinators and pollination functions across the continent in a highly integrated and synergistic way. Specifically, we are analysing the large-scale variability of pressures including habitat fragmentation, land use intensification, climate change, invasive species and regional spill-over effects, inter-annual land use dynamics, and local responses to experimental manipulations. Further, a network of sites provides an ideal platform to implement and test different mitigation strategies and monitoring schemes at an appropriate European scale.

The project will yield new knowledge, at relevant spatial and temporal scales, on where multiple drivers impact on pollinators at genetic, species and community levels. Standardised data for genetic diversity and fruit set of wild plant populations and yields of crops provide a basis for the assessment of functional and economic risks of pollinator loss. Further, STEP will contribute important data for improving methods for a future European pollinator monitoring programme and for different mitigation strategies to enhance pollinator diversity and ensure pollination services in agroecosystems.

\section{Theme 6: European policy tools and integration} of knowledge

At present, European policy instruments rarely explicitly take into account pollinator conservation or the management of pollination services. Several policy areas have, however, major direct and indirect impacts on pollinators, including, inter alia: agriculture, rural development, conservation and trade. Reform of the EU's Common Agricultural Policy (CAP) in 1992 has had major consequences for the management of rural environments across the continent, including changes that may have direct or indirect impacts on pollinator populations and pollination services. New agri-environmental schemes have been introduced that include some measures that are explicitly designed to support pollinator populations (e.g. incentives for introducing flower-rich field margins; Meek et al., 2002; Carvell et al., 2004), and many other land management options (low input, or organic farming) may have indirect or unintended consequences for pollinators. Of particular relevance are policies governing the use of pesticides and other agrochemicals, which are known to have negative effects on pollinators if not used appropriately (e.g. Alston et al., 2007). 
In general, however, the resulting net impacts of many agrienvironment scheme measures on pollinator populations and pollination service provision are not well known and evaluation of the effectiveness of options for improving pollination is needed (Kleijn et al., 2006). Both agricultural and environmental policy contribute to the development of agri-environmental measures. In practice, however, these measures are a minor part of the total structure of the CAP and there still appears to be a detachment of environmental and agricultural policy goals. This problem challenges the demand for transparency, for minimising decision uncertainty and for effective use of existing knowledge; indeed the principles for an effective integration to solve such problems are not well developed.

Current European biodiversity conservation policy is well developed, but tends to focus on the protection of species (often charismatic ones) or habitats, and pollinators are not explicitly included (e.g. EU Communication, 2006: Halting the loss of biodiversity by 2010 - and beyond, Sustaining ecosystem services for human well-being). Many broad policies relating to general biodiversity conservation (e.g. European Strategy for the Conservation of Invertebrates of the Council of Europe) are, however, likely to have positive impacts on pollinators. Recent policy developments (e.g. EU Communication 2010: Options for an EU vision and target for biodiversity beyond 2010) encompass ecosystem services with biodiversity conservation and are increasingly taking into account a wide range of services. Legislation relating to plant and pollinator conservation is not always implemented uniformly across the EU. For example, the exclusion of managed pollinators from protected areas varies across Member States, with some countries allowing honey bees to be kept within protected areas, whereas other countries strictly prohibit it (e.g. Belgium). The evidence is unclear on whether managed honey bees pose a risk to other pollinators in protected areas through pathogen transmission or resource competition, and harmonisation of policies between member states is lacking.

The STEP project will bring together the findings from our research and integrate it into a framework relevant for policy development. This will allow pollination objectives to be incorporated into policymaking in environmental and non-environmental policy sectors. This integration will take place at different spatial levels in order to be effective and to recognise the importance of national and continental ecological and social conditions. Specifically, STEP will evaluate evidence and provide recommendations to identify mechanisms within CAP reform which will provide better conservation and management of pollination services through instruments such as agri-environment schemes. STEP will also provide a better understanding of the conservation priorities for pollinators and support policy development with appropriate knowledge (e.g. outcomes of the Red Data Book for European bees). We will increase our understanding of the risks of keeping managed pollinators within protected areas and provide regional assessments across Europe to help make national policies more coherent. The project will also quantify current and future risks associated with importing and transporting managed pollinators, both into Europe and within Europe, and so provide evidence to develop more effective trade and import regulations and provide a precautionary framework for reducing the risk of new invasive pests of pollinators from entering Europe and for dealing with the consequences should pests become established.

\section{Theme 7: Communication, dissemination and training}

Loss of pollinators affects virtually all members of society. Hence, the main target groups for the communication and dissemination of the results of STEP cover specialists and non-specialists and include: 1 . decision makers, administrators, and managers in agricultural businesses and landscape planning; 2 . scientists; 3 . beekeepers, veterinarians, horticulturists, farmers; and 4 . the general public. STEP will therefore go beyond conventional means of dissemination of project results to academic societies and policy makers to reach the widest possible audience.

STEP's communication and dissemination strategy combines traditional methods of dissemination (papers in journals, printed materials) with advanced, more (inter-)active technologies (online open access publications, e-books, email newsletters, STEP Online Library, WikiSTEP module as part of WikiCOLOSS, Facebook and Twitter). Special emphasis is laid upon integrating STEP into existing international networks and organisations, such as COLOSS, ICPBR, EurBee, IBRA, APIMONDIA, ProMellifera and others.

\section{Conclusions}

Despite credible progress in describing and understanding the extent of declines in pollinators across Europe and the causes of loss, there still remain many critical gaps in our knowledge. In particular, knowledge on the status and trends of, and pressures on, non-Apis pollinators is largely lacking. Furthermore, for all pollinators the consequences of their loss for agriculture and wider biodiversity are poorly studied, and adaptation and mitigation options to overcome losses are only partially developed. While COLOSS and other initiatives are addressing some of these challenges relating to honey bees, STEP remains the only large scale project dedicated to conducting research across the full spectrum of pollinators found in Europe. STEP will make a significant contribution to: 1 . strengthening European capacity to assess the conservation status and trends of pollinators and animal -pollinated plants; 2. improving our understanding of drivers of pollinator decline and associated economic risks, of interdependence and causal links between decline of pollinator and pollinated species, and of relationships between pollinator decline and environmental 
degradation; 3. enhancing capacities to quantify economic and ecological values of pollination; and 4. providing options to halt pollinator decline and assure that pollination services remain resilient for sustainable agriculture. In all cases, STEP will strive to deliver robust scientific evidence to support the development of practical management options and policy development to ensure the conservation of pollinators and sustainable delivery of pollination services under current and future environmental change in Europe.

\section{Acknowledgements}

We thank two anonymous referees for their suggestions to improve the manuscript. STEP is funded by the European Commission as a Collaborative Project within Framework 7 under grant 244090 - STEP $-\mathrm{CP}-\mathrm{FP}$.

\section{References}

AGUILAR, R; ASHWORTH, L; GALETTO, L; AIZEN, M A (2006) Plant reproductive susceptibility to habitat fragmentation: review and synthesis through a meta-analysis. Ecology Letters 9: 968-980. DOI: $10.1111 / j .1461-0248.2006 .00927 . x$

AIZEN, M A; GARIBALDI, L A; CUNNINGHAM, S A; KLEIN A M (2008) Long-term global trends in crop yield and production reveal no current pollination shortage but increasing pollinator dependency. Current Biology 18: 1-4. DOI: 10.1016/j.cub.2008.08.066

ALBRECHT, M; DUELLI, P; MÜLLER, C; KLEIJN, D; SCHMID, B (2007) Effects of a Swiss agri-environment scheme on pollinator communities and seed set of plants in nearby intensely managed farmland. Journal of Applied Ecology 44: 813-822. DOI: 10.1111/ j.1365-2664.2007.01306.x

ALSTON, D G; TEPEDINO, V J; BRADLEY, B A; TOLER, T R; GRISWOLD, T L; MESSINGER, S M (2007) Effects of the insecticide phosmet on solitary bee foraging and nesting in orchards of Capitol Reef National Park, Utah. Environmental Entomology 36 : 811-816. DOI: 10.1603/0046-225X(2007)36[811:EOTIPO]2.0.CO;2 ASHMAN, T L; KNIGHT, T.M; STEETS, J A; AMARASEKARE, P; BURD, M; CAMPBELL D R; DUDASH, M R; JOHNSTON, M O; MAZER, S J; MITCHELL R J; MORGAN, M T; WILSON, W G (2004). Pollen limitation of plant reproduction: ecological and evolutionary causes and consequences. Ecology 85: 2408-2421. DOI: 10.1890/03-8024 BARTOMEUS, I; VILÀ, M; STEFFAN-DEWENTER, I (2010) Combined effects of Impatiens glandulifera invasion and landscape structure on native plant pollination. Journal of Ecology 98: 440-450. DOI: 10.1111/j.1365-2745.2009.01629.x
BATÁRY, P; BÁLDI, A; SÁROSPATAKI, M; KOHLER, F; VERHULST, J; KNOP, E; HERZOG, F; KLEIJN, D (2010) Effects of conservation management on bees and insect-pollinated grassland plant communities in three European countries. Agriculture, Ecosystems and Environment 136: 35-39. DOI: 10.1016/j.agee.2009.11.004

BENGTSSON, J; AHNSTROM, J; WEIBULL, A C (2005) The effects of organic agriculture on biodiversity and abundance: a meta-analysis. Journal of Applied Ecology 42: 261-269. DOI: 10.1111/j.13652664.2005.01005.x

BIESMEIJER, J C; ROBERTS, S P M; REEMER, M; OHLEMÜLLER, R; EDWARDS, M; PEETERS, T; SCHAFFERS, A P; POTTS, S G; KLEUKERS, R; THOMAS, C D; SETTELE, J; KUNIN, W E (2006) Parallel declines in pollinators and insect-pollinated plants in Britain and the Netherlands. Science 313: 351-354.

DOI: $10.1126 /$ science. 1127863

BOMMARCO, R; BIESMEIJER, J C; MEYER, B.; POTTS, S G; PÖYRY J; ROBERTS, S P M; STEFFAN-DEWENTER, I; ÖCKINGER, E (2010) Dispersal capacity and diet breadth modify the response of wild bees to habitat loss. Proceedings of the Royal Society B-Biological Sciences 277: 2075-2082. DOI: 10.1098/rspb.2009.2221

BOSCH, J; KEMP, W P (2005) Alfalfa leafcutting bee population dynamics, flower availability, and pollination rates in two Oregon alfalfa fields. Journal of Economic Entomology 98: 1077-1086. DOI: $10.1603 / 0022-0493-98.4 .1077$

BROWN, M J F; PAXTON, R J (2009) The conservation of bees: a global perspective. Apidologie 40: 410-416. DOI: 10.1051/ apido/2009019

BRITTAIN, C A; VIGHI, M; BOMMARCO, R; SETTELE, J; POTTS, S G (2010) Impacts of a pesticide on pollinator species richness at different spatial scales. Basic and Applied Ecology 11: 106-115. DOI: $10.1016 /$ j.baae.2009.11.007

BRÜCKMANN, S; KRAUSS, J; STEFFAN-DEWENTER, I (2010) Butterfly and plant specialists suffer from reduced connectivity in fragmented landscapes. Journal of Applied Ecology 47: 799-809. DOI: $10.1111 / j .1365-2664.2010 .01828 . x$

BURD, M (1994) Bateman's principle and reproduction: the role of pollinator limitation in fruit and seed set. Botanical Review 60: 83139. DOI: $10.1007 / B F 02856594$

CARVELL, C; MEEK, W R; PYWELL, R F; NOWAKOWSKI, M (2004) The response of foraging bumble bees to successional change in newly created arable field margins. Biological Conservation 118: 327-339. DOI: 10.1016/j.biocon.2003.09.012

CARVELL, C; ROY, D B; SMART, S M; PYWELL, R F; PRESTON, C D; GOULSON, D (2006) Declines in forage availability for bumble bees at a national scale. Biological Conservation 132: 481-489. DOI: $10.1016 /$ j.biocon.2006.05.008 
COX-FOSTER, D L; CONLAN, S; HOLMES, E. C; PALACIOS, G; EVANS J D; MORAN, N A; QUAN, P L; BRIESE, T; HORNIG, M; GEISER, D. M; MARTINSON, V; VANENGELSDORP, D; KALKSTEIN, A L; DRYSDALE, A; HUI, J; ZHAI, J H; CUI, L W; HUTCHISON, S K; SIMONS, J F; EGHOLM, M; PETTIS, J S; LIPKIN W I (2007) A metagenomic survey of microbes in honey bee Colony Collapse Disorder. Science 318: 283-287. DOI: 10.1126/science.1146498 DAUBER, J; BIESMEIJER, J C; GABRIEL, D; KUNIN, W E; LAMBORN, E; MEYER, B; NIELSEN, A; POTTS, S G; ROBERTS, S P M; SÕBER, V; SETTELE, J; STEFFAN-DEWENTER, I; STOUT, J C; TEDER, T; TSCHEULIN, T; VIVARELLI, D; PETANIDOU, T (2010) Effects of patch size and density on flower visitation and seed set of wild plants: a pan-European approach. Journal of Ecology 98: 188196. DOI: $10.1111 /$ j.1365-2745.2009.01590.x

DE LA RÚA, P; JAFFÉ, R; DALL'OLIO, R; MUÑOZ, I; SERRANO, J (2009) Biodiversity, conservation and current threats to European honey bees. Apidologie 40: 263-284. DOI: 10.1051/apido/2009027 DICKS, L V; SHOWLER, D A; SUTHERLAND, W J (2010) Bee conservation: evidence for the effects of interventions. Synopses of Conservation Evidence. Pegasus Publishing, Exeter.

DORMANN, C F; SCHWEIGER, O; AUGENSTEIN, I; BAILEY, D; BILLETER, R; DE BLUST, G; DEFILIPPI, R; FRENZEL, M; HENDRICKX, F; HERZOG, F; KLOTZ, S; LIIRA, J; MAELFAIT, J P; SCHMIDT, T; SPEELMANS, M; VAN WINGERDEN, W; ZOBEL, M (2007) Effects of landscape structure and land-use intensity on similarity of plant and animal communities. Global Ecology and Biogeography 16: 774-787. DOI: 10.1111/j.1466-8238.2007.00344.x

EU COMMUNICATION (2006) Halting the loss of biodiversity by 2010 and beyond, Sustaining ecosystem services for human well-being. $\operatorname{COM}$ (2006) 216 final.

EU COMMUNICATION (2010) Options for an EU vision and target for biodiversity beyond 2010. COM (2010) 4 final.

FREEMAN, S (2009) Towards a method for the estimation and use of averaged multispecies trends, as indicators of patterns of change in butterfly populations. UKBMS Technical Report.

GABRIEL, D; TSCHARNTKE, T (2007) Insect pollinated plants benefit from organic farming. Agriculture Ecosystems and Environment 118: 43-48. DOI: 10.1016/j.agee.2006.04.005

GÄRDENFORS, U (Ed.) (2010) Rödlistade arter i Sverige 2010 - The 2010 Red List of Swedish Species. ArtDatabanken, SLU; Uppsala, Sweden.

GALLAI, N; SALLES, J M; SETELLE, J; VAISSIERE, B E (2009)

Economic valuation of the vulnerability of world agriculture confronted to pollinator decline. Ecological Economics 68: 810-821. DOI: $10.1016 /$ j.ecolecon.2008.06.014

GOULSON, D (2003) Effects of introduced bees on native ecosystems. Annual Review of Ecology Evolution and Systematics 34: 1-26. DOI: 10.1016/S0006-3207(01)00088-X
GOULSON, D; LYE, G C; DARVILL, B (2008) Decline and conservation of bumble bees. Annual Review of Entomology 53: 191-208. DOI: 10.1146/annurev.ento.53.103106.093454

GREGORY, R D; VAN STRIEN, A (2010) Wild bird indicators: using composite population trends of birds as measures of environmental health. Ornithological Science 9: 3-22. DOI: 10.2326/osj.9.3

HAMBÄCK, P A; BERGMAN, K-O; BOMMARCO, R; KRAUSS, J; KUUSSAARI, M; PÖYRY, J; ÖCKINGER, E (2010) Allometric density responses in butterflies: The response to small and large patches by small and large species. Ecography 33: 1149-1156. DOI: 10.1111/j.1600-0587.2009.06125.x

HAMBÄCK, P A; SUMMERVILLE, K S; STEFFAN-DEWENTER, I; KRAUSS, J; ENGLUND, G; CRIST, T O (2007) Habitat specialization, body size, and family identity explain lepidopteran density-area relationships in a cross-continental comparison. Proceedings of the National Academy of Sciences USA 104: 83688373. DOI: $10.1073 /$ pnas.0611462104

HEARD, M S; CARVELL, C; CARRECK, N L; ROTHERY, P; OSBORNE, J L; BOURKE, A F G (2007) Landscape context not patch size determines bumble-bee density on flower mixtures sown for agrienvironment schemes. Biology Letters 3: 638-641. DOI: 10.1098/ rsbl.2007.0425

HEGLAND, S J; NIELSEN, A; LÁZARO, A; BJERKNES, A L; TOTLAND, $\varnothing$ (2009) How does climate warming affect plant-pollinator interactions? Ecology Letters 12 : 184-195. DOI: 10.1111/j.14610248.2008.01269.x

HEGLAND, S J; TOTLAND, $\varnothing ~(2008)$ Is the magnitude of pollen limitation in a plant community affected by pollinator visitation and plant species specialisation levels? Oikos 117: 883-891. DOI: 10.1111/j.0030-1299.2008.16561.x

HERRMANN, F; WESTPHAL, C; MORITZ, R F A; STEFFAN-DEWENTER I (2007) Genetic diversity and mass resources promote colony size and forager densities of a social bee (Bombus pascuorum) in agricultural landscapes. Molecular Ecology 16: 1167-1178. DOI: 10.1111/j.1365-294X.2007.03226.x

HICKLING, R; ROY, D B; HILL, J K; FOX, R; THOMAS, C D (2006) The distributions of a wide range of taxonomic groups are expanding polewards. Global Change Biology 12: 450-455. DOI: 10.1111/ j.1365-2486.2006.01116.x

HÖHN, P; TSCHARNTKE, T; TYLIANAKIS, J M; STEFFAN-DEWENTER, I (2008) Functional group diversity of bee pollinators increases crop yield. Proceedings of the Royal Society B-Biological Sciences 275: 2283-2291. DOI: 10.1098/rspb.2008.0405

HOLZSCHUH, A; STEFFAN-DEWENTER, I; KLEIJN, D.; TSCHARNTKE, T (2007) Diversity of flower-visiting bees in cereal fields: Effects of farming system, landscape composition and regional context. Journal of Applied Ecology 44: 41-49. DOI: 10.1111/j.13652664.2006.01259.x 
HOLZSCHUH, A; STEFFAN-DEWENTER, I; TSCHARNTKE, T (2008)

Agricultural landscapes with organic crops support higher pollinator diversity. Oikos 117: 354-361. DOI: 10.1111/ j.2007.0030-1299.16303.x

KEVAN, P G (1999) Pollinators as bioindicators of the state of the environment: species, activity and diversity. Agriculture Ecosystems \& Environment 74: 373-393. DOI: 10.1016/S01678809(99)00044-4

KLEIJN, D; BAQUERO R A; CLOUGH, Y; DÍAZ, M; DE ESTEBAN, J; FERNÁNDEZ, F; GABRIEL, D; HERZOG, F; HOLZSCHUH, A; JÖHL, R; KNOP, E; KRUESS, A; MARSHALL, E J P; STEFFAN-DEWENTER, I; TSCHARNTKE, T; VERHULST, J; WEST, T M; YELA, J L (2006) Mixed biodiversity benefits of agri-environment schemes in five European countries. Ecology Letters 9: 243-254.

DOI: $10.1111 / j .1461-0248.2005 .00869 . x$

KLEIJN, D; RAEMAKERS, I (2008) A retrospective analysis of pollen host plant use by stable and declining bumble bee species. Ecology 89: 1811-1823. DOI: 10.1890/07-1275.1

KLEIN, A. M; VAISSIERE, B E; CANE, J H; STEFFAN-DEWENTER, I; CUNNINGHAM, S A; KREMEN, C; TSCHARNTKE, T (2007) Importance of pollinators in changing landscapes for world crops. Proceedings of the Royal Society B-Biological Sciences 274: 303313. DOI: $10.1098 / \mathrm{rspb} .2006 .3721$

KLEYER, M; BEKKER, R M; KNEVEL, I C; BAKKER, J P; THOMPSON, K; SONNENSCHEIN, M; POSCHLOD; VAN GROENENDAEL, J M; KLIMES, L; KLIMESOVA, J; KLOTZ, S; RUSCH, G M; HERMY, M; ADRIAENS, D; BOEDELTJE, G; BOSSUYT, B; DANNEMANN, A; ENDELS, P; GOTZENBERGER, L; HODGSON, J G; JACKEL, A K; KUHN, I; KUNZMANN, D; OZINGA, W A; ROMERMANN, C; STADLER, M; SCHLEGELMILCH, J; STEENDAM, H J; TACKENBERG, O; WILMANN, B; CORNELISSEN, J H C; ERIKSSON, O; GARNIER, E; PECO, B (2008) The LEDA Trait base: a database of life-history traits of the Northwest European flora. Journal of Ecology 96: 1266-1274. DOI: 10.1111/j.1654-1103.2003.tb02188.x

KLOTZ, S; KÜHN, I; DURKA, W (2002) BIOLFLOR - Eine Datenbank mit biologisch-ökologischen Merkmalen zur Flora von Deutschland. Bundesamt für naturschutz; Bonn, Germany.

KOHLER, F; VERHULST, J; KNOP, E; HERZOG, F; KLEIJN, D (2007) Indirect effects of grassland extensification schemes on pollinators in two contrasting European countries. Biological Conservation 135: 302-307. DOI: 10.1016/j.biocon.2006.10.037

KOHLER, F; VERHULST, J; VAN KLINK, R; KLEIJN, D (2008) At what spatial scale do high-quality habitats enhance the diversity of forbs and pollinators in intensively farmed landscapes? Journal of Applied Ecology 45: 753-762. DOI: 10.1111/j.13652664.2007.01394.x
KREMEN, C; WILLIAMS, N; AIZEN, M A; GEMMILL-HERREN, B; LEBUHN, G; MINCKLEY, R; PACKER, L; POTTS, S G; ROULSTON, T; STEFFAN-DEWENTER, I; VAZQUEZ, D P; WINFREE, R; ADAMS, L; CRONE, E E; GREENLEAF, S S; KEITT, T H; KLEIN, A-M; REGETZ, J; RICKETTS, T H (2007) Pollination and other ecosystem services produced by mobile organisms: a conceptual framework for the effects of land-use change. Ecology Letters 10: 299-314.

DOI: $10.1111 / j .1461-0248.2007 .01018 . x$

KUUSSAARI, M; BOMMARCO, R; HEIKKINEN, R K; HELM, A; KRAUSS, J; LINDBORG, R; ÖCKINGER, E; PÄRTEL, M; PINO, J; RODÀ, F; STEFANESCU, C; TEDER, T; ZOBEL, M; STEFFAN-DEWENTER, I (2009) Extinction debt: a challenge for biodiversity conservation. Trends in Ecology and Evolution 24: 564-571.

DOI: $10.1016 / j$.tree.2009.04.011

LAVERGNE, S; MOLINA J; DEBUSSCHE, M (2006) Fingerprints of environmental change on the rare Mediterranean flora: a 115-year study. Global Change Biology 12: 1466-1478. DOI: 10.1111/ j.1365-2486.2006.01183.x

LENNARTSSON, T (2002) Extinction thresholds and disrupted plantpollinator interactions in fragmented plant populations. Ecology 83: 3060-3072. DOI: 10.1890/0012-9658(2002)083[3060:ETADPP]2.0.CO;2 LILLELEHT, V (Ed.) (1998) Red Data Book of Estonia. Threatened Fungi, Plants and Animals. Tartu, Estonia.

MACCAGNANI, B; BURGIO, G; STANISAVLJEVI/E, L Z; MAINI, S (2007) Osmia cornuta management in pear orchards. Bulletin of Insectology 60: 77-82.

MACE, G M; COLLAR, N; GASTON K J; HILTON-TAYLOR, C; AKCAKAYA, H R; LEADER-WILLIAMS, N; MILNER-GULLAND, E J; STUART, S N (2008) Quantification of extinction risk: IUCN's system for classifying threatened species. Conservation Biology 22: 1424-1442. DOI: 10.1111/j.1523-1739.2008.01044.x MACE, G M; LANDE, R (1991) Assessing extinction threats: toward a re-evaluation of the IUCN threatened species categories. Conservation Biology 5: 148-157. DOI: 10.1111/j.15231739.1991.tb00119.x

MATSUMURA, C; YOKOYAMA, J; WASHITANI, I (2004) Invasion status and potential ecological impacts of an invasive alien bumble bee, Bombus terrestris L. (Hymenoptera: Apidae) naturalized in Southern Hokkaido, Japan. Global Environmental Research 8: 51-66.

MEEK, B; LOXTON, D; SPARKS, T; PYWELL, R; PICKETT, H; NOWAKOWSKI, M (2002) The effect of arable field margin composition on invertebrate biodiversity. Biological Conservation 106: 259-271. DOI: 10.1016/S0006-3207(01)00252-X

MEMMOTT, J; CRAZE, P G; PRICE, M V; WASER, N M (2007) Global warming and the extinction of ecological interactions. Ecology Letters 10: 710-717. DOI: 10.1111/j.1461-0248.2007.01061.x 
MEYER, B; JAUKER, F; STEFFAN-DEWENTER, I (2009) Contrasting resource-dependent responses of hover fly richness and density to landscape structure. Basic and Applied Ecology 10: 178-186. DOI: $10.1016 /$ j.baae.2008.01.001

NATURAL RESEARCH COUNCIL (2006) Status of Pollinators in North America. National Academic Press.

NEUMANN, P; CARRECK, N L (2010) Honey bee colony losses. Journal of Apicultural Research 49: 1-6. DOI: 10.3896/IBRA.1.49.1.01

ÖCKINGER, E; SCHWEIGER, O; CRIST, T; DEBINSKI, D; KRAUSS, J; KUUSSAARI, M; PETERSEN, J; PÖYRY, J; SETTELE, J; SUMMERVILLE, K; BOMMARCO, R (2010) Life-history traits predict species responses to habitat area and isolation - A cross-continental synthesis. Ecology Letters 13: 969-979. DOI: 10.1111/j.14610248.2010.01487.x

ÖCKINGER, E; SMITH, H G (2007) Semi-natural grasslands as population sources for pollinating insects in agricultural landscapes. Journal of Applied Ecology 44: 50-59. DOI: 10.1111/ j.1365-2664.2006.01250.x

OLLERTON, J; WINFREE, R; TARRANT, S (2011) How many flowering plants are pollinated by animals? Oikos 120: 321-326. DOI: $10.1111 / j .1600-0706.2010 .18644 . x$

OTTERSTATTER, M C; THOMSON, J D (2008) Does pathogen spillover from commercially reared bumble bees threaten wild pollinators? PLOS ONE 3(7): e2771. DOI: 10.1371/journal.pone.0002771

POTTS, S G; BIESMEIJER, J C; KREMEN, C; NEUMANN, P; SCHWEIGER, O; KUNIN, W E (2010a) Global pollinator declines: trends, impacts and drivers. Trends in Ecology and Evolution 25: 345-353. DOI: $10.1016 / j$.tree.2010.01.007

POTTS, S G; ROBERTS, S P M; DEAN, R; MARRIS, G; BROWN, M; JONES, R; SETTELE, J (2010b) Declines of managed honey bees and beekeepers in Europe. Journal of Apicultural Research 49: 15-22. DOI: 10.3896/IBRA.1.49.1.02

RAND, T A; TYLIANAKIS, J M; TSCHARNTKE, T (2006): Spillover edge effects: the dispersal of agriculturally subsidized insect natural enemies into adjacent natural habitats. Ecology Letters 9: 603614. DOI: 10.1111/j.1461-0248.2006.00911.x

RASMONT, P; LECLERCQ, J; JACOB-REMACLE, A; PAULY, A; GASPAR, $C$ (1993). The faunistic drift of Apoidea in Belgium. In E. Bruneau (Ed.) Bees for pollination. Commission of the EC; Brussels, Belgium. pp. 65-87.

RASMONT, P; MERSCH, P (1988) Première estimation de la derive faunique chez les bourdons de la Belgique (Hymenoptera, Apidae). Annales de la Société Royale zoologique de Belgique 118: 141-147.

RASMONT, P ; PAULY, A ; TERZO, M ; PATINY, S ; MICHEZ, D ; ISERBYT, S ; BARBIER, Y ; HAUBRUGE, E (2005) The survey of wild bees (Hymenoptera, Apoidea) in Belgium and France. FAO; Rome, Italy.
RICKETTS, T H; REGETZ, J; STEFFAN-DEWENTER, I; CUNNINGHAM, $S$ A; KREMEN, C; BOGDANSKI, A; GEMMILL-HERREN, B; GREENLEAF, S S; KLEIN, A M; MAYFIELD, M M; MORANDIN, L A; OCHIENG, A; POTTS, S G; VIANA, B F (2008) Landscape effects on crop pollination services: are there general patterns? Ecology Letters 11: 499-515. DOI: 10.1111/j.1461-0248.2008.01157.x RORTAIS, A; ARNOLD, G; HALM, M P; TOUFFET-BRIENS, F (2005) Modes of honey bees exposure to systemic insecticides: estimated amounts of contaminated pollen and nectar consumed by different categories of bees. Apidologie 36: 71-83. DOI: 10.1051/ apido:2004071

RUNDLÖF, M; NILSSON, H; SMITH, H G (2008) Interacting effects of farming practice and landscape context on bumble bees. Biological Conservation 22: 343-349. DOI: 10.1016/ j.biocon.2007.10.011

SCHWEIGER, O; BIESMEIJER, J C; BOMMARCO, R; HICKLER, T; HULME, P E; KLOTZ, S; KÜHN, I; MOORA, M; NIELSEN, A; OHLEMÜLLER, R; PETANIDOU, T; POTTS, S G; PYŠEK, P; STOUT, J C; SYKES, M T; TSCHEULIN, T; VILÁ, M; WALTHER, G R; WESTPHAL, C; WINTER, M; ZOBEL, M; SETTELE, J (2010) Multiple stressors on biotic interactions: how climate change and alien species interact to affect pollination. Biological Reviews 85: 777-795. DOI: 10.1111/j.1469-185X.2010.00125.x

SCHWEIGER, O; HEIKKINEN, R K; HARPKE, A; HICKLER, T; KLOTZ, S; KUDRNA, O; KÜHN, I; PÖYRY, J; SETTELE J (2011) Increasing range mismatching of interacting species under global change is related to their ecological characteristics. Global Ecology and Biogeography (in press).

SCHWEIGER, O; MAELFAIT, J P; VAN WINGERDEN, W; HENDRICKX, F; BILLETER, R; SPEELMANS, M; AUGENSTEIN, I; AUKEMA, B; AVIRON, S; BAILEY, D; BUKACEK, R; BUREL, F; DIEKOTTER, T; DIRKSEN, J; FRENZEL, M; HERZOG, F; LIIRA, J; ROUBALOVA, M; BUGTER, R (2005) Quantifying the impact of environmental factors on arthropod communities in agricultural landscapes across organizational levels and spatial scales. Journal of Applied Ecology 42: 1129-1139. DOI: 10.1111/j.1365-2664.2005.01085.x SCHWEIGER, O; MUSCHE, M; BAILEY, D; BILLETER, R; DIEKOTTER, T; HENDRICKX, F; HERZOG, F; LIIRA, J; MAELFAIT, J P; SPEELMANS, M; DZIOCK, F (2007) Functional richness of local hover fly communities (Diptera, Syrphidae) in response to land use across temperate Europe. Oikos 116: 461-472.

DOI: $10.1111 / j .2007 .0030-1299.15372 . x$

SETTELE, J; KUDRNA, O; HARPKE, A; KÜHN, I; VAN SWAAY, C; VEROVNIK, R; WARREN, M; WIEMERS, M; HANSPACH, J; HICKLER, T; KÜHN, E; VAN HALDER, I; VELING, K; VLEIGENHART, A; WYNHOFF, I; SCHWEIGER, O (2008) Climatic risk atlas of European butterflies. BioRisk 1: 1-710. DOI: 10.3897/ biorisk. 1 
SPEIGHT, M C D (2010) Species accounts of European Syrphidae (Diptera) 2010. Syrph the Net, the database of European Syrphidae, vol.59, 285 pp. Syrph the Net publications; Dublin, Ireland.

STEFFAN-DEWENTER, I (2003) Importance of habitat area and landscape context for species richness of bees and wasps in fragmented orchard meadows. Conservation Biology 17: 1036-1044.

STEFFAN-DEWENTER, I; MUNZENBERG, U; BURGER, C; THIES, C; TSCHARNTKE, T (2002) Scale-dependent effects of landscape context on three pollinator guilds. Ecology 83: 1421-1432. DOI: 10.1007/s10841-006-9058-1

STEFFAN-DEWENTER, I; SCHIELE, S (2008) Do resources or natural enemies drive bee population dynamics in fragmented habitats? Ecology 89: 1375-1387. DOI: 10.1890/06-1323.1

STEFFAN-DEWENTER, I; TSCHARNTKE, T (2000) Butterfly community structure in fragmented habitats. Ecology Letters 3: 449-456. DOI: $10.1111 / j .1461-0248.2000 .00175 . x$

STOUT, J C; MORALES, C L (2009) Ecological impacts of invasive alien species on bees. Apidologie 40: 388-409. DOI: 10.1051/ apido/2009023

THOMSON, D M (2006) Detecting the effects of introduced species: A case study of competition between Apis and Bombus. Oikos 114: 407-418. DOI: 10.1111/j.2006.0030-1299.14604.x

TRAVESET, A; RICHARDSON, D M (2006) Biological invasions as disruptors of plant reproductive mutualisms. Trends in Ecology and Evolution 21: 208-216. DOI: 10.1016/j.tree.2006.01.006 TSCHARNTKE, T; KLEIN, A-M; KRUESS, A; STEFFAN-DEWENTER, I; THIES, C (2005) Landscape perspectives on agricultural intensification and biodiversity - ecosystem service management. Ecology Letters 8: 857-874. DOI: 10.1111/j.14610248.2005.00782.x

TYLIANAKIS, J M; DIDHAM, R K; BASCOMPTE, J; WARDLE, D A (2008) Global change and species interactions in terrestrial ecosystems. Ecology Letters 11: 1351-1363. DOI: 10.1111/j.14610248.2008.01250.x

VAN SWAAY, C; CUTTELOD, A; COLLINS, S; MAES, D; LOPEZ MUNGUIRA, M; ŠAŠIĆ, M; SETTELE, J; VEROVNIK, R; VERSTRAEL, T; WARREN, M; WIEMERS, M; WYNHOF, I (2010) European Red List of Butterflies. Publications Office of the European Union; Luxembourg.

VELTHUIS, H H W; VAN DOORN, A (2006) A century of advances in bumble bee domestication and the economic and environmental aspects of its commercialization for pollination. Apidologie 37: 421 -451. DOI: $10.1051 /$ apido:2006019
VILÀ, M; BASNOU, C; PYŠEK, P; JOSEFSSON, M; GENOVESI, P; GOLLASCH, S; NENTWIG, W; OLENIN, S; ROQUES, A; ROY, D; HULME, P E; ANDRIOPOULOS, P; ARIANOUTSOU, M; AUGUSTIN, S; BACHER, S; BAZOS, I; BRETAGNOLLE, F; CHIRON, F; CLERGEAU, P; COCHARD, P O; COCQUEMPOT, C; COEUR DACIER, A; DAVID, M; DELIPETROU, P; SPREZ-LOUSTAU, M L; DIDZIULIS, V; DORKELD, F; ESSL, F; GALIL, B S; GASQUEZ, J; GEORGHIOU, K; HEJDA, M; JAROŠÍK, V; KARK, S; KOKKORIS, I; KÜHN, I; LAMBDON, P W; LOPEZ-VAAMONDE, C; MARCER, A; MIGEON, A; MCLOUGHLIN, M; MINCHIN, D; NAVAJAS, M; PANOV, V E; PASCAL, M; PERGL, J; PERGLOVA, I; PINO, J; POBOLJSAJ, K; RABITSCH, W; RASPLUS, J Y; SAUVARD, D; SCALERA, R; SEDLACEK, O; SHIRLEY, S; WINTER, M; YANNITSAROS, A; YART, A; ZAGATTI, P; ZIKOS, A (2010) How well do we understand the impacts of alien species on ecosystem services? A pan-European, cross-taxa assessment. Frontiers in Ecology and the Environment 8: 135-144. DOI: $10.1890 / 080083$

WESTPHAL, C; BOMMARCO, R; LAMBORN, E; PETANIDOU, T; POTTS, S G; ROBERTS, S P M; SZENTGYÖRGYI, H; VAISSIÈRE, B E; WOYCIECHOWSKI, M; STEFFAN-DEWENTER I (2008) Measuring bee diversity in different habitats and biogeographic regions. Ecological Monographs 78: 653-671. DOI: 10.1890/07-1292.1 WESTPHAL, C; STEFFAN-DEWENTER, I; TSCHARNTKE, T (2003) Mass flowering crops enhance pollinator densities at a landscape scale. Ecology Letters 6: 961-965. DOI: 10.1046/j.1461-0248.2003.00523.x WESTPHAL, C; STEFFAN-DEWENTER, I; TSCHARNTKE, T (2006) Bumble bees experience landscapes at different spatial scales: possible implications for coexistence. Oecologia 149: 289-300. DOI: $10.1007 / \mathrm{s} 00442-006-0448-6$

WILLIAMS, I H (1994) The dependence of crop production within the European Union on pollination by honey bees. Agricultural Zoology Reviews 6: 229-257.

WILLIAMS, N M; CRONE, E E; ROULSTON, T H; MINCKLEY, R L; PACKER, L; POTTS, S G (2010) Ecological and life history traits predict bee species responses to environmental disturbances. Biological Conservation 143: 2280-2291.

DOI: $10.1016 /$ j.biocon.2010.03.024

WINFREE, R; AGUILAR, R; VAZQUEZ, D P; LEBUHN, G; AIZEN, M A (2009) A meta-analysis of bees' responses to anthropogenic disturbance. Ecology 90: 2068-2076. DOI: 10.1890/08-1245.1 